\title{
High Purity Composite Briquette for Direct UMG-Si Production in Arc Furnaces
}

\author{
Raymond Perruchoud* and Jean-Claude Fischer \\ $R \& D$ Carbon Ltd \\ P.O. Box 362, ,CH-3960, Sierre, Switzerland
}

Received 27.02.2017, received in revised form 11.03.2017, accepted 23.03.2017

In the Metallurgical Grade Si (MG-Si), the B and P contents are in average above 30 ppm as the carbon reduction materials used in the arc furnace are either rich in $B$ (coal) or in $P$ (charcoal). A decrease of both impurities by a factor 3 by using purer raw materials would allow the direct production of the Upgraded Metallurgical Grade (UMG).This would significantly improve the efficiency of the resulting PV cells made with the refined Solar Grade Silicon (SoG-Si) or decrease massively the costs of Si purification by shortening the number of steps needed for reaching $B$ and $P$ contents below 1 ppm requested for the SoG-Si used for the PV cells.

A composite $\mathrm{C} / \mathrm{SiO}_{2}$ briquette fulfilling the purity targets for the direct production of UMG-Si in arc furnace was developed. The composite contains several carbon materials with different levels of reactivities and quartz sand. The raw materials aspects, the paste and briquette preparation, as well as the final carbonization step are commented. The finished briquettes are free of volatiles and are mechanically and thermally very stable, thus ensuring stable arc furnace charges with minimum losses of dust and SiO gas. Semi-industrial trials including the downstream purification steps for the production of SoG-Si by a metallurgical low cost route are contemplated.

Keywords: Photovoltaic cells, metallurgical silicon, arc furnace, raw materials.

DOI: $10.17516 / 1998-2836-0006$.

(C) Siberian Federal University. All rights reserved

* Corresponding author E-mail address: info@rd-carbon.com 


\title{
Композитные брикеты высокой чистоты \\ для прямого производства металлургического кремния глубокой очистки в дуговых электропечах
}

\section{Раймонд Перручоуд, Жан-Клод Фишер \\ R\&DCarbonLtd \\ Швейщария, 3960 Sierre, а/я 362}

\begin{abstract}
В металлургчческом кремнии (MG-Si) содержание В и $P$ в среднем превышает 30 ррт, так как в применяемых в дуговых печах материалах, восстанавливаемых углеродом, содержание В (уголь) или Р (древесньй уголь) высокое. Уменьшение содержания обеих примесей в три раза при использовании сырья более высокой чистоты могло бы обеспечить прямое производство металлургического кремния глубокой очистки. При этом существенно повысится эффективность солнечных батарей, изготовленных из кремния солнечного качества, произведенного по данной технологии рафинирования, благодаря уменьшению количества этапов, необходимых для снижения содержания B или $P$ ниже 1 ррт, в соответствии с требованиями к кремнию солнечного качества, используемому для прочзводства солнечных батарей, снизится стоимость очистки $\mathrm{Si}$. Композитный брикет $\mathrm{C} / \mathrm{SiO}_{2}$, отвечаюший требованиям чистоты, разработан для прямого производства металлургического кремния глубокой очистки в дуговой печи. Композит содержит квариевый песок и несколько углеродных материалов с различными уровнями реакционной способности газа и кварцевого песка. Рассматриваются некоторые аспекты сырьевых материалов, подготовки массы и брикетов, а также окончательный этап карбонизации, проведенной в вертикальной ретортной печи. Готовые брикеты не содержат летучих, отличаются высокой механической и термической устойчивостью, что обеспечивает стабильность загрузки дуговой печи с минимальными потерями пьли и газообразного SiO. Рассматриваются результаты полупромышленных испытаний, включающих последующче этапь очистки для производства кремния солнечного качества по металлургической схеме наименьшей стоимости.
\end{abstract}

Ключевые слова: фотоэлементы, металлургический кремний, дуговые электропечи, сырьевые материаль.

\section{From metallurgical Si to photovoltaic cells}

The reduction of quartz raw materials with carbon materials in arc furnaces delivers MG-Si with purity close to $99 \%(2 \mathrm{~N})$. The efficiency of PV cells is among other things strongly influenced by the $\mathrm{P}$ and $\mathrm{B}$ contents of the Si.

The figure 1 shows that it reaches a maximum plateau for concentrations below $0.1 \mathrm{ppm}$. Therefore downgraded electronic $\mathrm{Si}(8 \mathrm{~N}$ to $6 \mathrm{~N}$ ) was, and is still, used for PV applications. UMG-Si is not competitive as the loss in efficiency exceeds $10 \%$ rel. but remains the preferred feedstock for the preparation of SoG-Si (better than $6 \mathrm{~N}$ ) by using a metallurgical refining low cost route. 


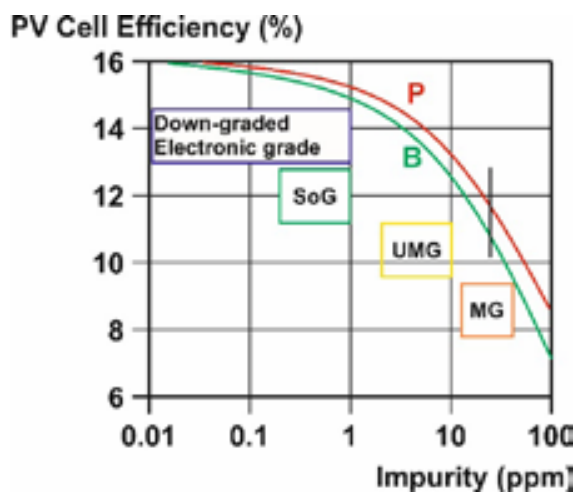

Fig.1. B and P impact on the cell efficiency. Redrawn from [1]

Where are $\mathrm{P}$ and $\mathrm{B}$ impurities in the MG-Si coming from? Beside the 2.5 tons of quartzite containing some ppm of $\mathrm{P}$, the arc furnace process requires about 1 ton of several carbon reduction and electrode materials. Up to six C containing materials can therefore be used namely, woodchips, charcoal, coal, petcoke and anthracite based paste with graphite core electrodes.

The wood and charcoal are rich in $\mathrm{P}$ while the coal based products are rich in $\mathrm{B}$. The level of $\mathrm{P}$ loss from the carbon reduction materials reaches $90 \%$. From the quartzite, melting only in the lower hot part of the furnace, the P loss is unfortunately lower (about 50\%). More than $90 \%$ of B present in any raw materials is found in the metal [2].

The metallurgical route of purification during cooling of liquid $\mathrm{Si}$ involves segregation of impurities by directional solidification. This works not very well for P and B for which the coefficients of segregation (the ratio of concentration in solid versus the one in liquid) reach high values close to 1. At least one refining step is therefore needed with typical MG-Si for lowering their concentration below 10 ppm to obtain UMG-Si, the feedstock of the SoG-Si.

Petroleum based coke material would be ideal reduction material from a purity point of view, but its amount in the charge is limited to some percent only, due to the lack of reactivity to $\mathrm{SiO}$ gas [3] or to liquid $\mathrm{SiO}_{2}$ for the formation of intermediate $\mathrm{SiC}$ prior its transformation to $\mathrm{Si}$ [4].

An excess of low reactivity carbon leads to poor efficiency and high energy consumption as well as to furnace operation difficulties. However higher percentage of such low reactivity carbon have been used successfully, providing intimate contacts with finely distributed quartz favour the reaction rates. This intimate contact means a production of composite briquettes with relatively fine quartz sand which is bounded with a suitable organic material, a concept already used in the eighties that was revisited and eventually improved by using the state of the art technologies for paste and carbonized briquettes preparation.

\section{Behaviour of composite $\mathrm{C} / \mathrm{SiO}_{2}$ briquettes in furnaces}

\section{Conventional charges components}

With conventional lumps of quartzite the selection of the carbon blends is made according to the reactivity to $\mathrm{SiO}$ as high reactivity carbons trap the $\mathrm{SiO}$ in the outer zone of the furnace by transforming it into SiC. High reactivity being correlated with the porosity of the carbon material the 
preferred source is charcoal as during the carbonization of the wood more than $85 \%$ of volatiles create a maximum of pores. Chars from non-coking coal ( $40 \%$ of volatiles) have also an interesting high reactivity, but metallurgical cokes from coking coal and especially petroleum cokes are far less porous and therefore show low reactivity to $\mathrm{SiO}$.

\section{Reaction mechanisms with composite briquettes}

It is astonishing that briquettes with calcined coke materials from coking coal, green coke and coal tar pitch (Ancit briquettes) were operating well. From one side the faster melting of the fine quartz together with the intimate contact with the carbon components is quickly producing the needed $\mathrm{SiC}$ in the intermediate zone of the furnace. Another possible explanation is that the preferred reaction involving $\mathrm{SiC}$ and liquid $\mathrm{SiO}_{2}$ in the inner hottest zone is the one producing no $\mathrm{SiO}$ but only $\mathrm{Si}$, namely the reaction $5^{*}$ as shown in the Fig. 2.

It was also observed that the reaction volume of the charge was much larger with briquettes, so that the velocity of the off-gas through the charge channels was reduced. Last but not least, the homogeneity of the charge was massively improved as the homogenization of the several raw materials having much different bulk densities and granulometries by simple stocking vehicle was, and remains, a tedious operation step.

Therefore less $\mathrm{SiO}$ reactive carbon components can do a correct job in term of efficiency and energy consumption. The ideal reaction sequence of briquette components for a $100 \%$ yield is shown in Fig. 2. The composite briquette still contains a relatively porous $(\mathrm{Cp})$ and reactive carbon reacting with $\mathrm{SiO}$ but also an equivalent part of more dense carbon $(\mathrm{Cd})$ that will react with $\mathrm{SiO}_{2}$ later in the intermediate zone. The formed $\mathrm{SiC}$ will react with liquid $\mathrm{SiO}_{2}$ from the molten lump quartzite in the lower inner part of the arc furnace.

\section{Carbosil Briquette Process}

The strength and weakness of the raw materials and process used in the past (Ancit and Silgro industrial briquettes) were revisited and a composite briquette concept, delivering a product named Carbosil, was developed. Emphasis was given in producing a briquette that is maintaining its strength and integrity during the transformation process related to the formation of $\mathrm{SiC}$, from $\mathrm{C}$ reacting with the $\mathrm{SiO}$ oxidant gas or later with $\mathrm{SiO}_{2}$.

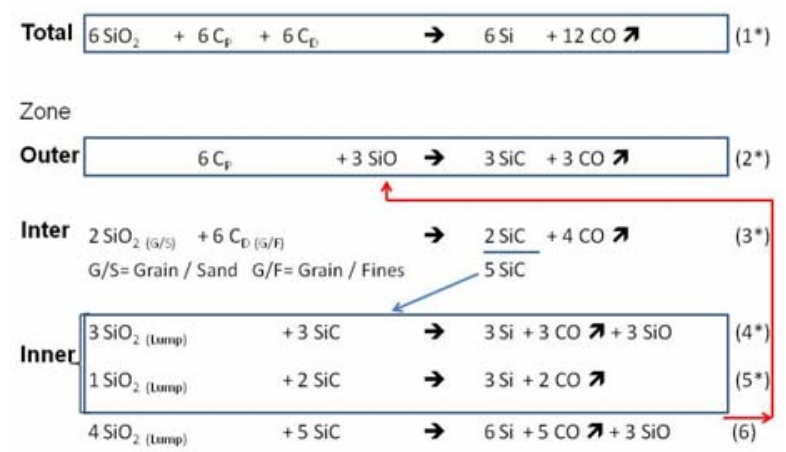

Fig. 2. Possible reaction sequences with composite briquettes and quartzite lumps [4] 


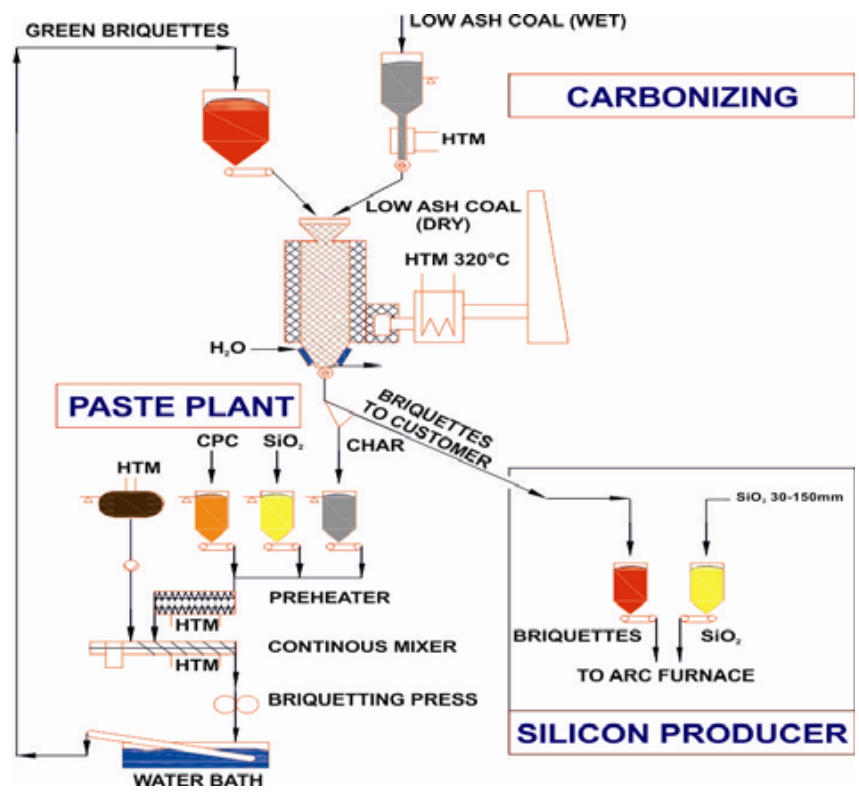

Fig. 3. Carbosil plant flow sheet

The original idea of the patented concept [5] is the co-carbonization process where the green briquettes are smoothly carbonized in a vertical retort together with one or more granular green carbons that will serve as carbonized raw materials for the production of the paste. The flow sheet shown in Fig. 3 shows the cycle process where eventually the finished briquettes are separated from the granular carbon by sieving.

\section{Carbosil Pilot Composite Briquettes}

\section{Pilot plant and testing tools (Fig. 4)}

The green granular carbons are carbonized preliminarily in a vertical pilot retort at a final temperature close to $750^{\circ} \mathrm{C}$. The carbon dry aggregate is prepared by crushing, sieving in continuous pilot roller crushers and multi-decks sieving machine. The most important step, which is the fines preparation, requests an air jet collision mill equipped with an air classifier for controlling the fineness.

The batches of dry aggregate recipe are preheated before mixing in an intensive propeller mixer. The paste is cooled by water addition to the right temperature before the pressing of $20 \mathrm{~cm}^{3}$ briquettes. The green briquettes are co-carbonized with the corresponding amount of green materials that are later integrated in the manufacture of the green briquettes.

\section{Physical characteristics of Carbosil briquettes}

The Table 1 shows the results of briquettes of similar dimensions and geometry with a level of $\mathrm{C} / \mathrm{SiO}_{2}$ weight ratio of 1 corresponding to a molar ratio of 5. The apparent density of the Carbosil composite briquette is the highest and its load strength reach unprecedented high levels thanks efficient mixing of the optimized dry aggregate mainly. 

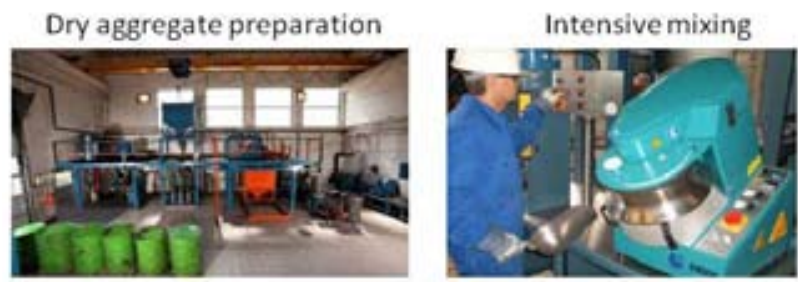

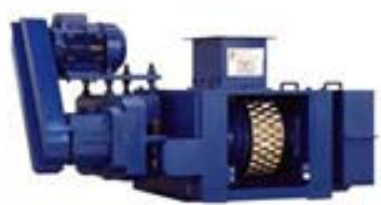

Briquetting press

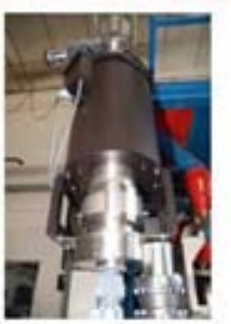

Vertical retort

Fig. 4. Pilot Plant equipment for Carbosil briquettes

Table 1. Comparison of Carbosil to previous industrial briquettes (Ancit and Silgro)

\begin{tabular}{|l|c|c|c|c|}
\hline \multicolumn{1}{|c|}{ Properties } & Unit & ANCIT & SILGRO & Carbosil \\
\hline Apparent density & $\mathrm{Kg} / \mathrm{dm}^{3}$ & 1.49 & 1.35 & 1.52 \\
\hline Load strength & $\mathrm{Kg}$ & 120 & 80 & 140 \\
\hline Loss in $\mathrm{CO}_{2}$ & $\%$ & 14 & 18 & 13 \\
\hline Dust in $\mathrm{CO}_{2}$ & $\%$ & 11 & 54 & 9 \\
\hline Ratio loss / dust & - & 1.2 & 0.3 & 3 \\
\hline Volatiles & $\%$ & 4 & 6 & 0.2 \\
\hline Non $\mathrm{SiO}_{2}$ ash & $\%$ & 3 & 2 & 1.4 \\
\hline
\end{tabular}

The most encouraging data is the low selective burning and good integrity of the briquettes after the $\mathrm{CO}_{2}$ reactivity test. The ratio loss to dust of the Carbosil briquettes reaches 4 times the Silgro value and is superior to the Ancit briquettes used with good success in the past.

\section{Impact of Carbosil on the Si metal purity}

\section{$B$ and $P$ from the charge components into the metal}

Boron oxides show boiling point above $3000{ }^{\circ} \mathrm{C}$ so that the majority $(90 \%)$ of the incoming impurity will be transferred into the metal. For $\mathrm{P}$ different distributions were observed as its volatility from the carbon reduction material is as expected high (10\% only in Si metal), but intermediate $(50 \%)$ for the $\mathrm{P}$ impurities integrated in the large size quartzite lumps reacting only in the inner zone of the furnace.

\section{Conventional charge situation for $B$ and $P$ in the $M G-S i$}

For a comparison basis we can consider the production of MG-Si where raw materials purity and charge composition are selected in such a way to get an equal contamination of B and $\mathrm{P}$ in the metal. 
The Tables 2 and 3 show that due to the high content of $\mathrm{B}$ in coal or char and of $\mathrm{P}$ in charcoal a blend of carbon raw materials is mandatory.

With charcoal, coal and char as main reduction materials in conventional charges a content of $35 \mathrm{ppm}$ of both elements $\mathrm{B}$ and $\mathrm{P}$ is found in the MG-Si metal. With such a high level of these critical elements for the efficiency of the PV cells little can be done in the selection of more expensive purer raw materials so that emphasis remains the selection of cheap raw materials for the MG- Si producer. This means much higher refining costs for the SoG-Si preparation.

\section{Carbosil composite briquettes in the charge}

The maximisation of petcoke content, which is much higher than in the in the conventional charge and this without operation and yield drawbacks, is decisive for reducing the contamination of both elements B and P. With this scenario of 2 tons of Carbosil (one ton each of $\mathrm{C}$ and $\mathrm{SiO}_{2}$ ) together with

Table 2. Raw materials characteristics in conventional charges

\begin{tabular}{|l|c|c|c|c|}
\hline \multirow{2}{*}{ Raw materials } & \multirow{2}{*}{ Moisture, \% } & \multirow{2}{*}{ Ash, \% } & \multicolumn{2}{c|}{ Dry basis } \\
\cline { 4 - 5 } & & & B, ppm & P, ppm \\
\hline Charcoal & 5 & 2 & 5 & 140 \\
\hline Coal & 10 & 1.5 & 40 & 10 \\
\hline Char & 5 & 2 & 60 & 5 \\
\hline Green coke & 10 & 0.5 & 3 & 60 \\
\hline Woodchips & 33 & 1 & 1 & 10 \\
\hline Electrode & 0 & 2 & 10 & 10 \\
\hline Quartzite A & 0 & $0.8 *$ & 2 & 5 \\
\hline
\end{tabular}

* non- $\mathrm{SiO}_{2}$ oxyde

Table 3. B and P in Si metal with conventional charges

\begin{tabular}{|c|c|c|c|c|}
\hline Components & $\mathrm{Kg} / \mathrm{t} \mathrm{Si}$ & Ash, $\%$ & $\mathrm{~B}, \mathrm{ppm}$ & $\mathrm{P}, \mathrm{ppm}$ \\
\hline Charcoal & 600 & 1.2 & 3 & 133 \\
\hline Coal & 300 & 0.4 & 11 & 3 \\
\hline Char & 300 & 0.6 & 17 & 4 \\
\hline Green coke & 50 & 0 & 0 & 0 \\
\hline Woodchips & 2000 & 2 & 2 & 80 \\
\hline Electrode & 100 & 0 & 1 & 1 \\
\hline$\Sigma$ from $\mathrm{C}$ materials & & 4.2 & 33 & 221 \\
\hline$\%$ in Si metal & & & 90 & 10 \\
\hline In $\mathrm{Si}$ from $\mathrm{C}$ materials & & & 30 & 22 \\
\hline From Quartzite A & 2500 & 2.0 & 5 & 25 \\
\hline$\%$ in Si metal & & & 90 & 50 \\
\hline In Si from Quartzite A & & & 5 & 13 \\
\hline Total in Si & & & 35 & 35 \\
\hline
\end{tabular}


Table 4. Raw materials characteristics with Carbosil in the charge

\begin{tabular}{|l|c|c|c|c|}
\hline \multirow{2}{*}{ Raw materials } & \multirow{2}{*}{ Moisture, \% } & \multirow{2}{*}{ Ash, \% } & \multicolumn{2}{c|}{ Dry basis } \\
\cline { 4 - 5 } & & & B, ppm & P, ppm \\
\hline Coal washed & 10 & 0.5 & 10 & 5 \\
\hline Green coke & 10 & 0.2 & 2 & 3 \\
\hline Coal tar pitch & 0 & 0.2 & 3 & 3 \\
\hline Woodchips & 33 & 1 & 1 & 3 \\
\hline Electrode & 0 & 0.5 & 2 & 1 \\
\hline Quartzsand & 0 & $0.3^{*}$ & 0 & 5 \\
\hline Quartzite B & 0 & $0.4^{*}$ & 1 & 60 \\
\hline
\end{tabular}

* non- $\mathrm{SiO}_{2}$ oxyde

Table 5. B and P in Si metal with Carbosil Briquettes

\begin{tabular}{|l|c|c|c|c|}
\hline \multicolumn{1}{|c|}{ Components } & Kg/t Si & Ash, \% & B, ppm & P, ppm \\
\hline Carbosil carbon & 1000 & 0.5 & 8 & 5 \\
\hline Woodchips & 1000 & 1.0 & 1 & 40 \\
\hline Electrode & 100 & 0 & 1 & 1 \\
$\Sigma$ from Carbosil carbon & & 1.5 & 10 & 46 \\
\hline \% in Si metal & & & 90 & 10 \\
\hline In Si from Carbosil carbon & 1000 & 0.3 & 9 & 5 \\
From Quartzsand & 1500 & 0.6 & 1 & 8 \\
From Quartzite B & & & 90 & 50 \\
\hline \% in Si metal & & & 1 & 5 \\
\hline In Si from Quartzite B & & & 10 & 10 \\
Total in Si & & & & 5 \\
\hline
\end{tabular}

1.5 ton of quartzite, a contamination of $10 \mathrm{ppm}$ only is obtained for both $\mathrm{B}$ and $\mathrm{P}$ elements (Tables 4 and 5).

The Si metal metal produced with the Carbosil briquettes, with 3 to 4 times less B and P than with conventional charges, meets the requirement of UMG-Si. The purity of the produced Si reaches $99.8 \%$.

The refining costs needed for reaching the threshold below $1 \mathrm{ppm}$ specified for the SoG-Si are therefore massively reduced.

\section{Conclusions}

In the race towards cost reduction of PV cells below $1 \$ / \mathrm{Wp}$ the direct production of UMG-Si in arc furnaces using high purity Carbosil briquettes plays an important role. A better purity of the SoG-Si, meanings a higher PV efficiency, reduces the investment costs and can bring the electricity generation to a competitive level for large scale power plant. 
The pilot scale works on these high purity briquettes have resulted in a plant basic design that can be fine tuned after semi-industrial trials have been performed.

The ideal partner embarking into such a project is a metallurgical Si producer having already developed a metallurgical refining route for the preparation of $\mathrm{SoG}-\mathrm{Si}$, a partner that is naturally eager to lower the refining production costs and to expand its production.

The collaboration with world class coal washing plants and high purity quartz sand producers can be contemplated as well. The access to an appropriate paste carbon plant remains mandatory for the validation phase where semi-industrial lots are tested and is a must for a smooth industrialization of the composite briquettes dedicated to the production of UMG-Si, the ideal feedstock for a low cost SoG-Si production.

\section{References}

1. Dégoulange J. Purification et caractérisations physico-chimiques et électriques de silicium d'origine métallurgique destiné à la conversion photovoltaïque. Thèse à l'Institut national polytechnique de Grenoble, 2008. 188 p.

2. Myrhaug E.H. and Tveit H. Material Balances of trace elements in the ferrosilicon and silicon processes. Electric furnace conference proceedings 2000. 591-604.

3. Tuset J.K. and Raaness O. Reactivity of reduction materials for the production of silicon, silicon-rich ferroalloys and Silicon carbide. Electric furnace conference St.-Louis. Innovation and improvement in metallurgical practices-Ferroalloys-II 1976. Vol. 34, p. 101-107.

4. Schei A. and Halvorsen S.A. A stoïchiometric model of the silicon process. Proceedings of the international symposium in honour of Ketil Motzfeldt May 24th 1991, p. 41-56

5. Patent 694271. Fischer J.C. and Perruchoud R. Kalzinierung von Briketts, 2009. 